\title{
A new species of the genus Raspinotus Kirejtshuk, 1990 (Coleoptera: Nitidulidae: Epuraeinae) from Sulawesi
}

\author{
Новый виА рода Raspinotus Kirejtshuk, 1990 \\ (Coleoptera: Nitidulidae: Epuraeinae) из Сумавеси
}

\begin{abstract}
A.G. Kirejtshuk ${ }^{1,2}$
А.Г. Кирейчук ${ }^{1,2}$

1'Zoological Institute of the Russian Academy of Sciences, Universitetskaya Emb., 1, Saint Petersburg 199034 Russia. E-mail: agk@zin.ru ${ }^{2}$ Muséum National d'Histoire Naturelle, CP 50, Entomologie, 45 rue Buffon, Paris F-75231 France

${ }^{1}$ Зоологический институт Российской академии наук, Университетская наб., 1, Санкт-Петербург 199034 Россия ${ }^{2}$ Национальный музей естественной истории, СР 50, Энтомология, ул. У. Бюффона, 45, Париж F-75231 Франция
\end{abstract}

Key words: Coleoptera, Nitidulidae, Epuraeinae, Raspinotus, new species, Indonesia, Sulawesi. Ключевые слова: Coleoptera, Nitidulidae, Epuraeinae, Raspinotus, новый виА, Индонезия, Сулавеси.

Abstract. Raspinotus limitaris sp. n. is described in the area boundary of both Indo-Malayan and Australian Regions. New data on the range of the genus Raspinotus in the Indian Province of the Indo-Malayan Region and Papuan Province of the Australian Region are given.

Резюме. Raspinotus limitaris sp. n. описан из района, пограничного Индо-Малайской и Австралийской областям. Приводятся новые данные по ареалу рода Raspinotus в Индийской провинции Индо-Малайской области и Папуасской провинции Австралийской обкасти.

The genus Raspinotus was proposed for carpophilinelike members of the subfamily Epuraeinae [Kirejtshuk, 1990]. The known species of it were mostly known from the Indochinese and Malayan Provinces of the Indo-Malayan Region [Kirejtshuk, 1990, 1994, 1998], although new materials increased the range of this genus spreading in the Indian Province [Kirejtshuk, 1998] (see also Material) and Papuan Province of the Australian Region (see also Material), and only one species is widely distributed throughout Africa southern of Sahara [Kirejtshuk, 1996] In this paper a new species of this genus from the boundary of Indo-Malayan and Australian Regions is described.

\section{Material}

The holotype of the new species is deposited in the collection of Staatliches Museum für Naturkunde in Stuttgart (Germany). Besides, among other data on this genus remained unpublished there are 1 male of Raspinotus combinatus (Kirejtshuk, 1994) from the collection of Zoological Institute of the Russian Academy of Sciences ("India: Dist. Along Arunanshal Pradesh, near Rapum, 6-12.vii.2010, 2000 hm, N28.53.176/E094.24941, Bretschneider"), 4 specimens of $R$. excellens (Kirejtshuk, 1990) from collections of the Oxford University Museum of Natural History (Great Britain) and Zoological Institute of the Russian Academy of Sciences ("Ceylon, Thwaites, 1873"), and also 1 male similar to R. spinicollis (Kirejtshuk, 1990) from the collection of Staatliches Museum für Naturkunde ("IrianJaya: Fakian, Kokas Inseln, Ogar, 13.vii.1996, Schüle/Stüben”).

Family Nitidulidae Latreille, 1802

Subfamily Epuraeinae Kirejtshuk, 1986

Tribe Taenioncini Kirejtshuk, 1998

Genus Raspinotus Kirejtshuk, 1990

Type species: Haptoncus depressus Grouvelle, 1897, recent.

\section{Raspinotus limitaris Kirejtshuk, sp. n. (Color plate 4: 1-6)}

Material. Holotype, §̊: "C. Sulawesi, $50 \mathrm{~m}, 6 \mathrm{~km}$ E Tambarana, 120.28.06E 1.11.15S, 9-11.July 1999, Bolm".

Description. Length of body 2.1, breadth 0.7, height $0.4 \mathrm{~mm}$. Rather convex dorsally and ventrally; bright reddish; with faint sheen, but middle of metasternum and ventrite 1 very shiny; body with fine and slightly conspicuous yellowish hairs, a little longer than distance between their insertions; pronotal and elytral sides densely ciliate. Head, pronotal and pygidial surface with shallow but more or less distinct punctures, about as large as eye facets, interspaces between them subequal or less than one puncture diameter, with cellular, fine and somewhat smooth microreticulation. Elytral surface similar to that on head and pronotum, but with shallower and much sparser punctures. Prosternal process with invisible punctation and finely alutaceous. Surface of metaventrite and ventrite 1 with distinct punctures somewhat smaller than eye facets and rather shallow, interspaces between them twice and more as broad as one puncture diameter, strongly smoothed. Head almost $2 / 3$ as long as distance between eyes; labrum moderately exposed from under frons and with shallow median excision. Antennae somewhat shorter than head broad, their club composing nearly a third of total antennal length, subovoid and with ultimate antennomere about 1.5 times as long as each of antennomeres 9 and 10. Pronotum subquadrangular and slightly transverse, with gently sloping sides and narrowly explanate lateral edges. Pygidium truncate apex. Ultimateast labial 


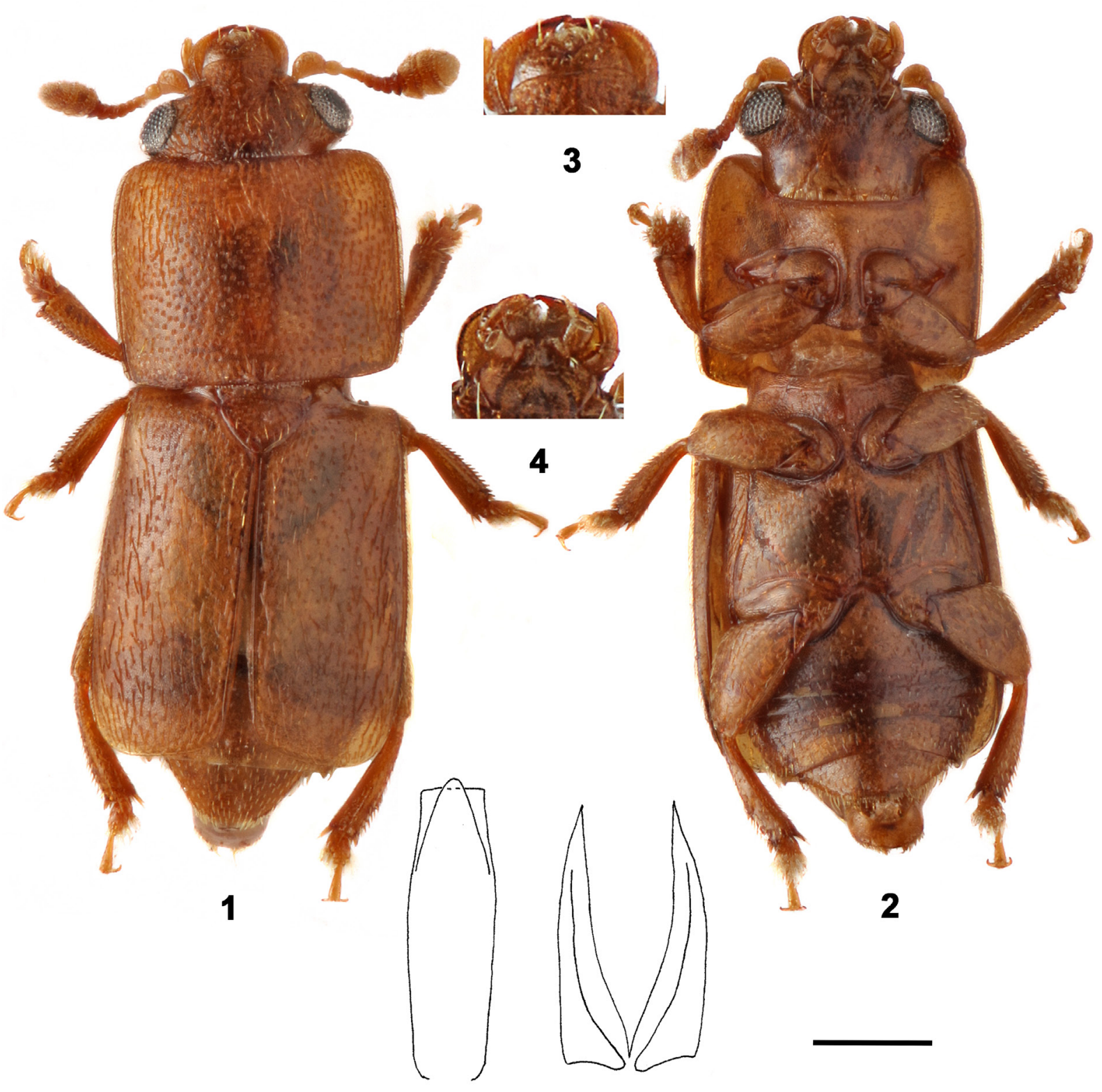

5

Figs 1-6. Raspinotus limitaris Kirejtshuk, sp. n., holotype, male (length of body $2.1 \mathrm{~mm}$ ).

1 - body, dorsal view; 2 - idem, ventral view; 3 - anterior part of frons and exposed mouthparts (labrum and mandibles), dorsal view; 4 - anterior part of head and exposed mouthparts (mentum, labial and maxillary palps, ligula and mandibles), ventral; 5 - penis trunk, dorsal view; 6 - tegmen, ventral view. Scale bar to Figs 5 and $6-0.1 \mathrm{~mm}$.

Рис. 1-6. Raspinotus limitaris Kirejtshuk, sp. n., голотип, самец (Алина тела 2.1 мм).

1 - тело, сверху; 2 - то же, снизу; 3 - передний край мба и выступающие ротовые части (кабрум и мандибулы), сверху; 4 - передний край головы и выступающие ротовые части (ментум, кабиальные и максимлярные щупики, кигула и мандибулы), снизу; 5 - ствол пениса, сверху; 6 - тегмен, снизу. Масштабная минейка к рисункам 5 и $6-0.1$ мм. 
palpomeres subcylindrical, slightly longer than thick. Prosterna process very slightly medially curved along procoxae. Distance between mesocoxae subequal to that between procoxae and that between metacoxae 1.5 times as great as that between procoxae. Mesoventrite moderately excavate. Metaventrite slightly convex and with angularly excised posterior edge between metacoxae. Epipleura about 2/3 as wide as antennal club. Tibiae short and wide, slightly narrower than antennal club; mesotibiae with convex outer edge and posterior ones subtriangular and sparse stout spines along outer edge. Anterior and mid femora $12 / 3$ times, but posterior one almost 3 times as wide as corresponding tibiae. Protarsi about $4 / 5$ as wide as corresponding tibiae, but meso- and metatarsi somewhat narrower; tarsal claws simple. Anal sclerite somewhat longer than aedeagus and with a pair of paramedian brushes of short hairs. Aedeagus slightly sclerotized.

Diagnosis. This new species is most similar to R. schawalleri Kirejtshuk, 1998 but differs from it in the less convex body, subcylindrical labial palpomere, slightly curved prosternal process along procoxae, narrower epipleura and simple tarsal claws. Absence of sexual dimorphism in the femora and tibiae of $R$. limitaris sp. n. makes it reminiscent of $R$. depressus, $R$. hospitus (Kirejtshuk, 1990), $R$. simples (Kirejtshuk, 1990) and R. spinicollis, however it is distinct by the subquadrate (not narrowing anteriorly and not arcuate at sides) pronotum with nearly straight (not emarginated) anterior edge, sparser and coarser puncturation of integument, less conspicuous pubescence, narrower epipleura, more or less markedly wider femora (particularly metafemora); besides, it differs also from the first in the posterior angles of pronotum widely rounded, obliterated sculpture of dorsum (including pronotum); from the third and fourth in the obliterated sculpture of dorsum (including pronotum). Finally, in contrast to most species with known males, the new species is also characterized by the very short paramedian brushes of hairs at the apex of the anal sclerite, and also by the subparallesided penis trunk.

Etymology. The epithet of the new species means "frontier", "limitary", "marginal" and "boundary".

\section{Acknowledgements}

The author is grateful to A.V. Kovalev (All-Russian Institute of Plant Protection of the Russian Academy of Agricultural Sciences, St. Petersburg - Pushkin, Russia) for his assistance in preparation of the photographs.

The studies were partly carried out under the framework of the Russian state research project No. 01201351189, Programme of the Presidium of the Russian Academy of Sciences "Problems of the origin of life and formation of the biosphere" and the Russian Foundation for Basic Research (grant 15-04-02971-a).

\section{References}

Kirejtshuk A.G. 1990. New species and notes on taxonomy of the nitiduldbeetles of Indochina and adjacent territories. Part 1. Proceedings of the Zoological Institute of the USSR Academy of Sciences. 209: 61-98 (in Russian

Kirejtshuk A.G. 1994. New species and notes on taxonomy of the nitiduldbeetles of Indochina and adjacent territories. Part 2. Proceedings of the Zoological Institute of the Russian Academy of Sciences. 257: 92-127 (in Russian).

Kirejtshuk A.G. 1996. Some results of study on the Nitidulidae from Namibia and adjacent territories. Part 1 (Coleoptera, Cucujoidea, Nitidulidae). Mitteilungen aus dem zoologischen Museum in Berlin. 76(1): 51-82.

Kirejtshuk A.G. 1998. Nitidulidae (Coleoptera) of the Himalayas and Northern Indochina. Part 1: subfamily Epuraeinae. (Theses Zoologicae, Vol. 28). Koeningstein: Koeltz Scientific Books. 489 p. 